\title{
COVID-19 Salgınının Uluslararası Güvenlik Açısından Değerlendirilmesi
}

\author{
Evaluation of COVID-19 Outbreak in Terms of International Security
}

\author{
Serkan Yenal*
}

\begin{abstract}
Many natural disasters took place at various times in human history, and certain countries, certain regions or continents were affected by these disasters. Throughout the history, there were great epidemics during the period, and as a result of these outbreaks, many people became ill and many died. When the outbreaks occurring are examined, it is seen that there are outbreaks sometimes created for attack purposes, sometimes naturally. While projections were being prepared for the past, the discovery of new technologies, the decreasing importance of borders and distances, safer and prosperous societies around the world are envisaged, but a global epidemic could not be predicted. Corona Virus, also called COVID-19, first appeared in Wuhan, China and spread to the whole world in weeks and became a global threat. The outbreak not only threatened human health, caused death and disease, but also became a huge security problem affecting many areas. Countries and institutions that have not faced such a problem for a long time have been caught unprepared for the epidemic, and within a short period of time the individual, national, environmental, educational, economic, etc. effects have emerged. In this study, all these factors were considered as the survivability of countries and were associated with security. Literature review method was used in the study. What extent will the epidemic's effects on national and international security be? How will the epidemic affect terrorism? What will be the role and function of security in the new world order after the epidemic? These questions will constitute the basic problematic of the study and it will be tried to find answers to these questions. The aim of the study is to reveal the effects of the epidemic on international security and to create predictions regarding the post-epidemic security.
\end{abstract}

StructuredAbstract: Introduction: Many natural disasters took place at various times in human history, and certain countries, certain regions or continents were affected by these disasters. Throughout the history, there were great epidemics during the period, and as a result of these outbreaks, many people became ill and many died. When the outbreaks occurring are examined, it is seen that there are outbreaks sometimes created for attack purposes, sometimes naturally.

While projections were being prepared for the past, the discovery of new technologies, the decreasing importance of borders and distances, safer and prosperous societies around the world are envisaged, but a global epidemic could not be predicted.

\footnotetext{
* *Dr. Öğr. Üyesi, Milli Savunma Üniversitesi, Kara Harp Okulu, Uluslararası İlişkiler Bölümü Asst. Prof. Dr., National Defense University, Turkish Military Academy, International Relations Department ORCID 0000-0002-8188-5095

serkanyenal@gmail.com, syenal@kho.edu.tr

Cite as/ Atıf: Yenal, S. (2020). COVID-19 salgınının uluslararası güvenlik açısından değerlendirilmesi. Turkish Studies, 15(4), 1315-1329. https://dx.doi.org/10.7827/TurkishStudies.43645

Received/Geliş: 16 May/Mayıs 2020

Accepted/Kabul: 10 August/Ağustos 2020

Copyright $\mathbb{C}$ MDE, Turkey
} 
Corona Virus, also called COVID-19, first appeared in Wuhan, China and spread to the whole world in weeks and became a global threat. The outbreak not only threatened human health, caused death and disease, but also became a huge security problem affecting many areas.

Countries and institutions that have not faced such a problem for a long time have been caught unprepared for the epidemic, and within a short period of time the individual, national, environmental, educational, economic, etc. effects have emerged. In this study, all these factors were considered as the survivability of countries and were associated with security.

The COVID-19 outbreak has affected a large number of people worldwide. As of April 2020, more than 300,000 people died, many were hospitalized, and many were infected. Accordingly, the threat of people's lives in the context of the "right to live", which is included in basic human rights, imposes important duties on both international organizations and countries. There is no country that is not under the influence of COVID19. Countries are under an obligation to make the necessary investments, supplies, to raise awareness of people, to have adequate hospitals, personnel and health supplies in order to secure their own citizens. The wrong decisions that can be taken in this area have a big and heavy effect. Taking this situation into consideration, it will be appropriate to take the necessary steps. The rate of spread of the epidemic, the absence of a proven treatment or vaccine, and the high numbers of deaths make people vulnerable. Along with the countries and international organizations taking the necessary measures, it is very important for the individuals to comply with the decisions to be taken and to take their own measures.

\section{The Aim of the Study}

The aim of the study is to reveal the effects of the epidemic on international security and to create predictions regarding the post-epidemic security.

For this aim, the following research questions were sought:

Q1: What extent will the epidemic's effects on national and international security be?

Q2: What How will the epidemic affect terrorism?

Q3: What will be the role and function of security in the new world order after the epidemic?

\section{The Importance of the Study}

The COVID-19 epidemic, which has emerged in China and spread to the whole world and will go down in history as one of the biggest disasters of the last period, creates effects in many areas in the world. Security is expected to be one of the most important problems in the world, which is left with many problems in terms of health, agriculture, environment, education and economy.

This study will determine the effects of the epidemic in the field of security and will present the measures that can be taken globally. In this way, the effects of the security problems that the epidemic can cause can be reduced.

\section{Methodology}

Literature review method was used in the study.

\section{Findings}

Outbreaks are not new to the world. However, the COVID-19 Outbreak brought new problems that have not been encountered for a long time. Individuals and countries could not take adequate measures against the epidemic they were caught off guard. The epidemic creates a new world order with big problems. Within this order, different formations occur in the field of security. Countries have to keep up with the new order to ensure their security. Here, individuals, countries and international organizations have an important role.

\section{Results}

In the security area, as in other areas, many things will not be the same after COVID-19. Problems experienced in other areas actually pose a security and survivability problem. Even the most developed countries find it difficult to overcome crises in vital sectors, which endangers the survivability of states and the safety of individuals. 
Today, the problems that countries may experience in times of crisis have emerged with painful experiences, and it has become imperative to find action plans for what can be experienced. The world should develop simulations against the worst scenarios, and prior studies should be conducted regarding the measures that can be taken when the risk occurs.

Considering that similar problems may be encountered in the future, countries should realize the necessary changes and transformations in security institutions such as armies, internal security units, intelligence agencies, taking into account the experience in the field of security. Since the security institutions are structured on the basis of being able to work in all conditions, they should make the necessary investments in the areas such as training, personnel employment, and the measures that can be taken in case of an outbreak.

Necessary conditions should be provided for the personnel to work without being affected by the epidemic by taking precautions both inside and outside the country at the point of ensuring the security of the countries.

Law enforcement and internal security mechanisms must effectively follow the implementation of the measures that can be taken and provide the necessary infrastructure for the protection of the health of the general public.

Since the destructive effect of biological tools such as bacteria and viruses is seen by the whole world, necessary defense mechanisms should be created against the use of these elements for weapons. Due to the increased potential of biological warfare, sufficient personnel should be employed for biological weapons in countries, and the efficiency of these personnel should be increased by providing continuous training.

Responsible units for outbreaks and biological weapons should be created in security agencies, and the efficiency and effectiveness of these units should be constantly monitored.

Necessary preparations should be made in order to prevent biological terrorist acts of terrorist organizations, and risk mechanisms should be evaluated and measures should be developed. Strategies should be developed to prevent people trained in these areas from taking part in the structures of terrorist organizations. In order to obtain intelligence, a multi-factor screening should be realized, and the necessary mechanisms should be established in the fight against these organizations by taking into consideration that the new generation of terrorist organizations are organized especially in the cyber space and continue their activities.

Sufficient personnel employment in the field of health intelligence, which can be accepted as a new intelligence field, should be ensured, and necessary studies should be carried out in order to gather intelligence and to resist intelligence.

Along with the national struggle in outbreaks, maximum coordination should be ensured with international organizations, policies such as the United Nations, NATO, European Union should be developed and their control should be developed.

The outbreak should be addressed at the United Nations Security Council and considered a threat to International Security. Decisions to be taken in this direction will have an important effect on the countries and will accelerate in the fight against the epidemic.

Keywords: International Relations, International Security, Security, Pandemic, COVID-19, Corona Virus

Öz: İnsanlık tarihinde çeşitli dönemlerde pek çok doğal afet gerçekleşmiş, belirli ülkeler, belirli bölgeler ya da kıtalar bu afetlerden etkilenmiştir. Tarih boyunca dönem dönem büyük salgınlar da yaşanmış, bu salgınlar neticesinde pek çok insan hastalanmış pek çoğu da hayatını kaybetmiştir. Meydana gelen salgınlar incelendiğinde kimi zaman, doğal olarak kimi zaman da bir saldırı amaçlı oluşturulan salgınlar bulunduğu görülmektedir. Geçmişte bugünler için projeksiyonlar hazırlanırken, yeni teknolojilerin keşfedilmesi, sınırların ve mesafelerin öneminin azalması, dünya genelinde daha güvenli ve müreffeh toplumlar öngörülmekteyken, küresel ölçekte bir salgın meydana gelebileceği tahmin edilememiştir. COVID-19 olarak da adlandırılan Corona Virüs türü ilk olarak Çin'in Wuhan kentinde ortaya çıkmış ve haftalar içinde bütün dünyaya yayılarak küresel bir tehdit halini almıştır. Salgın yalnızca insan sağlığını tehdit edip, ölüm ve hastalıklara yol açmamış, aynı zamanda pek çok alanı etkileyen devasa bir güvenlik sorunu haline gelmiştir. Bu boyutta bir sorunla uzun bir süredir karşılaşmayan ülke ve kurumlar, salgına büyük ölçüde hazırlıksız yakalanmış, kısa süre içerisinde 
salgının bireysel, ulusal, çevresel, eğitimsel, ekonomik vb. gibi etkileri ortaya çıkmıştır. Bu çalışmada bütün bu faktörler, ülkelerin beka sorunu olarak görülmüş ve güvenlikle ilişkilendirilmiştir. Çalışmada literatür incelemesi yöntemi kullanılmıștır. Salgının ulusal ve uluslararası güvenliğe yönelik etkileri hangi boyutta olacak? Salgın terörizmi nasıl etkileyecek? Salgın sonrası oluşacak yeni dünya düzeninde güvenliğin rolü ve işlevi ne olacak? Bu sorular çalışmanın temel problematiğini oluşturacak ve bu sorulara cevap bulunmaya çalışılacaktır. Çalışmada salgının uluslararası güvenlik üzerindeki etkilerinin ortaya çıkarılması ve salgın sonrasına ilişkin güvenlik açısından öngörüler oluşturulması amaçlanmaktadır.

Anahtar Kelimeler: Uluslararası İlişkiler, Uluslararası Güvenlik, Güvenlik, Salgın, COVID-19, Korona Virüs

\section{Giriş}

Kuşkusuz her yeni seneye farklı umutlar içinde girilmektedir. 2020 y1lı, birbiri ardına yaşanan şoklar neticesinde, hayal edilenden çok uzak bir yıl olma yolunda ilerlemektedir. Hızla gelişen teknoloji, uzay çağı, küreselleşme, robotlar beklenirken bütün dünyayı tehdit eden ve hiçbir bilinen tedavisi ya da aşısı bulunmayan bir salgınla karşı karşıya kalmış durumdadır.

Pek çok alanda bütün dünyayı kısa sürede etkisi altına alan salgın, büyük sorunların habercisi olmuştur. Yaşanan ölümler ve çok sayıda enfekte insanın yaşam mücadelesi ile birlikte, küresel ölçekte sağl1ksal, çevresel, ekonomik, büyük ölçekte sorunlar meydana gelmiştir. Yaşanan önemli sorunlardan bir tanesi de güvenlik alanındadır. Küresel salgın, uluslararası güvenliğe yönelik beklentilerde de önemli değişimlere neden olmuştur.

$\mathrm{Bu}$ çalışmada COVID-19 olarak da ifade edilen Corona Virüs salgınının ulusal ve uluslararası güvenliğe olan etkileri incelenecektir. Bu doğrultuda genel olarak güvenlik kavramına değinildikten sonra, küresel salgının güvenlik alanındaki etkileri çok boyutlu olarak incelenecektir.

\section{Kavramsal Çerçeve}

Arnold Wolfers güvenliği, "bir ulusun az ya da çok sahip olabileceği ve daha çok ya da az ölçüde sahip olmayı arzulayacağı bir değer" olarak tanımlamaktadır. Yine Wolfers'a göre güvenlik, "nesnel olarak edinilen değerlere yönelik tehditlerin yokluğunu ölçerken, öznel olarak da bu değerlere saldırılmasına ilişkin korkunun bulunmaması durumunu" ifade eder (Wolfers, 1952:484485). Wolfers bu tanımıyla ortaya koyduğu öznel ve nesnel anlamda güvenlik kavramını yazına kazandırmıştır. Aynı zamanda Wolfers'ın bu kavramsallaştırması ilerde oluşacak güvenlik çalışmalarına da farklı bir yön çizmiştir.

Güvenlikle ilgili çalışmaların gelişimine baktığımızda uzun süre realizm ekseninde ve devlet merkezli olarak gelişim gösterdiğini görebiliriz. Aslında bu durum siyasal realizmin doğasından kaynaklanmaktadır. Pek çok teorisyene göre, siyasal realizm, uluslararası ilişkiler teorileri içinde "en eski ve en baskın" teoridir. Merkezinde de "güvenlik kavramı" yer almaktadır. Realizm, devletlerin güvensizliğini, uluslararası ilişkilerin temel sorunu olarak görmektedir.Yine uluslararası sistem, "self help-kendi kendine yardım" düşüncesinin temel motivasyon olduğu bir alan olarak tasvir edilmektedir. $\mathrm{Bu}$ düşünceye göre, devletler kendi güvenliklerini kendileri sağlamak zorundadır; zira kendileri dışında güvenilebilecek başka hiçbir aktör yoktur (Walt, 2017). Bu şekilde realizmin liderliğinde ilerleyen güvenlik çalışmaları, sonraki süreçte güvenlik yazınına farklı bakış açılarının da girmesiyle genişlemiştir.

Devlet merkezli güvenlik anlayışı antik dönemde Thucydides'le başlayıp, 1648 Westfalya Antlaşması ile yükselişe geçen, 1815 Viyana Düzenlemesi, 1. Dünya Savaşı ve 2. Dünya Savaş1 sonrasında da Soğuk Savaş döneminde zirveye çıkan, bir süreci ifade etmektedir (Tuic Akademi, 2016). Soğuk Savaşın sona ermesi bir anlamda devlet merkezli uluslararası ilişkiler çalışmalarında, dolaylı olarak güvenlik çalışmalarında da bir değişimi getirmiştir. 
Soğuk Savaş’ın sona ermesiyle birlikte, birey, toplum, topluluk ve grupların güvenlik gereksinimleri artmış; konvansiyonel olmayan tehditlerin daha fazla gündeme gelmesi söz konusu olmuştur (Ovalı, 2006:4) Bu noktadan sonra artık bireylerin güvenliği de uluslararası ilişkiler ve güvenlik çalışmalarında kendine yer bulmaya başlamıştır.

Realizmin bütün güvenlik çalışmalarındaki baskın rolünün Soğuk Savaşın sona ermesiyle birlikte değişmeye başlamasıyla güvenliğe farklı bakış açılarından da yorumlar gelmeye başlamıştır. $\mathrm{Bu}$ alanda uluslararası ilişkiler yazınında kendine yer bulan eleştirel bakış, güvenlik çalışmalarına da eleştirel bir alt yapı oluşturmuştur. 90'lı yılların başlarında itibaren eleştirel teori, güvenlik çalışmalarında daha önce sorulan sorulara verilen cevapları sorgulamaya ve eleştirmeye başlamıştır. Eleştirel teori, kavramların veya teorinin doğasını sorgulayarak, ne bağlamda ve neden ortaya çıktığını aynı zamanda kime hizmet ettiğini araştırmaktadır (Kolasi, 2014:122-123).

Eleştirel güvenlik yaklaşımları, doğal olarak bir tehdit bulunmadığı iddiasındadır. Özünde hiçbir şey tehdit değildir ve olgular sosyo-politik kontrolden çıkma durumunda tehdit halini alır. Güvensizlik durumu ise, bu yapıda dışardan değil, içerden kaynaklanmaktadır. Barış ve güvenlik savaşlarla değil, şiddetsizlikle çözülebilir. Eleştirel güvenlik, birey merkezli yaklaşımı ile güvenlik kavramının kapsamını önemli ölçüde genişletmiş; güvenlik sağlamak yerine güvensizliğin kaynağına eğilmiştir (Birdişli, 2014:235-237). Eleştirel güvenlik ekolü ile birlikte, bireylerin de güvenlik algısının önemli bir parçası olduğu görüşü yaygınlaşmış, uluslararası ilişkiler yazınında birey odaklı çalışmalarda artış gerçekleşmiştir.

İlk kez 2019 Aralık'ta Çin'in Wuhan Eyaletinde görülen ve "2019-nCoV” olarak da bilinen virüs, Dünya Sağlık Örgütü (WHO) tarafindan 11 Şubat'ta "COVID-19(Corona Virus Disease 2019)" olarak adlandırılmış ve "pandemi" olarak ilan edilmiştir (BBC, 2020). Hızlı bir biçimde bütün dünyaya yayılan virüs, Aralık 2019-Haziran 2020 arasındaki süreçte 210 ülkeye yayılmış, tüm dünyada milyonlarca kişiye bulaşmış yarım milyona yakın kişinin ölümüne neden olmuştur. (Virus Ncov, 2020). Bu rakamlarla insanlığın uzun süredir yaşamadığı bir salgının, bütün dünyayı kısa sürede etkisi altına alması söz konusu olmuştur.

Aslında insanlık tarihinde salgınlara sıklıkla rastlanmaktadır. Pek çok insan tarihte gerçekleşen salgınlarla hayatını kaybetmiş, bu salgınlar tarihin akışını değiştirmişstir. Bunlardan özellikle çiçek virüsü, 12.000 yıldır bilinmekte ve dalgalar halinde gelen salgınlarla 300-500 milyon arasındaki insanı öldürdüğü tahmin edilmektedir. Diğer salgınlar ve özellikleri aşağıdaki tabloda ifade edilmektedir (Mph Online, 2020):

Tablo:1 Salgın Hastalıkların Tarihi Gelişimi

\begin{tabular}{|c|c|c|} 
HASTALIK & GÖRÜLDÜĞÜ DÖNEM & ÖLÜ SAYISI \\
\hline HIV & $1976-$ Halen & 36 milyon \\
\hline $\begin{array}{c}\text { Influenza A (Hong Kong } \\
\text { Gribi) }\end{array}$ & 1968 & 1 milyon \\
\hline Influenza A (Asya Gribi) & $1956-1958$ & 2 milyon \\
\hline Influenza (İspanyol Gribi) & 1918 & $30-50$ milyon \\
\hline 6. Kolera Salgını & $1910-1911$ & 800.000 \\
\hline $\begin{array}{c}\text { Influenza (Asya ya da Rusya } \\
\text { Gribi) }\end{array}$ & $1889-1890$ & 1 milyon \\
\hline 3. Kolera Salgın1 & $1852-1860$ & 1 milyon \\
\hline Hiyarciklı Veba & $1346-1353$ & $75-200$ milyon \\
\hline Justinian Vebas1 & $541-542$ & 25 milyon \\
\hline Antonine Vebas1 & 165 & 5 milyon \\
\hline
\end{tabular}

Kaynak: (MPH Online, 2020) 
Tablodan da anlaşılabileceği üzere, tarih boyunca çok sayıda salgın gerçekleşmiş, bir kısmı yerel bir kısmı ise küresel etki yaratmıştır. Gelmiş geçmiş en ölümcül vaka, 1346-1353 arasında yaşanan Hıyarcıklı Veba salgınıdır. 7 senelik bir periyotta 75 ile 200 milyon arasında can kaybı ile sonuçlandığı tahmin edilmektedir. Bu durum küresel bir salgının ortaya çıkarabileceği sonuçları göstermektedir.

Tarihi salgınlardan günümüzde yaşanan COVID-19 salgının seyri hakkında bazı çıkarımlar yapmak mümkündür. Buna göre, tarihi salgınlar, kısa süreli görülebildiği gibi birkaç seneyi kapsayan dönemlerde de gerçekleşebilmiştir. Bu durum COVID-19 salgınının ne zaman sonlanacağının kestirilmesinin şu aşamada mümkün olmadığını göstermektedir. Salgının sonlanması için hastalığa özel bir ilaç ya da aşının bulunması gerekmektedir. Halihazırda pek çok ülkede aşı geliştirme çalışmaları başlasa da bunlardan sonuç elde edilmesinin uzun zaman alabileceği değerlendirilmektedir.

\section{COVID-19'a Güvenlik Açısından Bakış}

Basit tanımıyla kendine yönelik tehditlerin bulunmaması hali olarak ifade edilebilen "güvenlik" kavramı, devletler açısından değerlendirildiğinde, çok faktörlü bir güvenlik algısı ortaya çıkmaktadır.

Devletlerin en önemli güvenlik kaygılarının başında kuşkusuz beka gelmektedir. Beka bir devletin varlığını ve bütünlüğünü sürdürmesi, vatandaşlarının huzur içinde yaşaması anlamında kullanılmaktadır. Yaşanmakta olan salgının küresel ve yerel boyutta önemli güvenlik sorunlarını da beraberinde getirdiği söylenebilecektir. Bu noktada, ekonomiden, sağllğa, silahlı kuvvetlerden tarıma, çevreden, uluslararası örgütleri içerecek biçimde, çok faktörlü bir değerlendirme yapılması gerekmektedir.

COVID-19 salgını dünya genelinde çok sayıda insanı etkilemiş durumdadır. 2020 Haziran Ayı itibariyle yarım milyona yakın kişi hayatını kaybetmiş, pek çoğu hastaneye yatmış, pek çoğu da enfekte olmuş durumdadır. Buna göre, temel insan hakları içinde yer alan "yaşama hakkı" bağlamında insanların yaşamlarının tehdit altında olması, hem uluslararası örgütlere, hem de ülkelere önemli görevler yüklemektedir.

COVID-19'un etkisi altına girmeyen bir ülke bulunmamaktadır. Ülkeler kendi vatandaşlarını güvence altına alabilmek için gerekli yatırımları, tedarikleri gerçekleştirmek, insanları bilinçlendirmek, yeterli hastane, personel ve sağlık malzemesi bulundurmak yükümlülüğü altındadır.

$\mathrm{Bu}$ alanda alınabilecek yanlış kararların etkisi büyük ve ağır olmaktadır. Bu durum gözetilerek gerekli adımların atılması yerinde olacaktır. Salgının yayılma hızı, kanıtlanmış bir tedavisinin ya da aşısının bulunmayışı, ölüm rakamlarının fazla oluşu insanları etkiye açık bırakmaktadır. Ülkeler ve uluslararası örgütlerin gerekli önlemleri almasıyla birlikte, bireylerin de alınacak kararlara uyması ve kendi tedbirlerini alması büyük önem arz etmektedir.

Bireysel ve toplumsal güvenliğini sağlayabilmek için salgınla ilgili tedbirler alınmalı, bireyler arasında farkındalığın artııılmasına ilişkin çalışma yapılmalıdır. Ulusal ve uluslararası boyutta salgının etkilerini azaltabilmek için, bireylerin dolaşımının sınırlanması, yalnızca gerekli durumlarda dışarı çıkmalarının sağlanması, kişisel ihtiyaç maddelerine ulaşılabilmesi ve paniğin önüne geçilebilmesi için tedarik imkânlarının artırılması fayda sağlayacaktır.

\section{Küresel Ekonomi, Sağlık ve Eğitim Boyutlarıyla COVID-19}

Küresel bir salgının kuşkusuz en büyük etki yarattığı sektörlerin başında sağlık sektörü gelmektedir. Gerek sağlık çalışanlarının çalışma koşulları, hastane ve sağlık kuruluşlarının kapasitesi, sistemin işleyişi, yapılan sağlık harcamaları, küresel salgından önemli oranda etkilenmektedir. Sağlık sektörünün bir ülkede etkili bir biçimde işleyebilmesi için asgari koşulların 
sağlanabilmesi, vatandaşlarının sağlığının korunması, ihtiyaç duyulduğu kadar sağlık personeli ve hastanenin bulunması gerekmektedir.

Sağlık sektöründe yaşanabilecek sorunların önlenebilmesi için, yeterli yatak ve ekipman sağlanması, sağlık çalışanlarının kendilerini salgından koruyabilmesi için gerekli önlemlerin alınması, sağlık çalışanlarına yönelebilecek şiddetin önüne geçilebilmesi için, sağlık çalışanlarını korumaya yönelik önlemler alınması gerekmektedir. Bütün bunlarda meydana gelebilecek aksamalar, pek çok insanın hayatına mal olabilecektir. Bu sebeple hassas bir biçimde önlemler değerlendirilmeli, gerekli çalışmalar zaman kaybedilmeden yürütülmelidir.

COVID-19 salgını çok boyutlu olarak pek çok sektörde etki yaratmıştır. Kaybedilen ve enfekte olan insanların haricinde en çok etkilediği alanlardan birisi ekonomidir. COVID-19 salgınının başlamasıyla birlikte pek çok ülkede kısmi ya da bütün ülkede ilan edilen sokağa çıkma ve şehir değiştirme yasaklamaları pek çok ülkede ekonomik faaliyetlerin durmasına neden olmuştur. Yasaklar ve pandeminin hızlı bir biçimde yayılmasının insanlar üzerinde yarattığı olumsuz etki sebebiyle küresel olarak büyük oranlı iş ve verim kaybı ile ciddi ekonomik kayıplar oluşmuştur.

Salgının sağlık harcamaları boyutu değerlendirildiğinde de yapılan harcamaların devasa boyutlarda olduğu görülmektedir.

İşletmelerin kapanması, turizm gelirlerinin sıfırlanması, işsizlik, vergi üretimi ve toplanma imkanlarının ortadan kalması, yapılan devasa sağlık harcamaları gibi unsurların toplanması neticesinde salgının küresel boyutta 2 trilyon dolardan-4,1 trilyon dolara yakın bir zarara ve küresel gayri safi hasıla kayıplarının da $\% 2,3$ ile $\% 4,8$ arasında gerçekleşmesi ve 2020 küresel olarak dünya ekonomisindeki küçülmenin \%2,2 olması beklenmektedir (Asya Kalkınma Bankası, 2020). Bu rakamlar dünya ekonomisinin salgın sebebiyle önemli kayıplar yaşayacağı ve küresel olarak ekonomik büyümenin önemli oranda yavaşlayacağını göstermektedir.

COVID-19 salgınının önemli bir etkisi de işgücü alanındadır. ILO'ya göre, Yaşanan krizin, 2020 yılının ikinci çeyreğinde küresel çalışma zamanlarının \%6,7'sini yok etmesi beklenmektedir ve bu oran yaklaşı 195 milyon tam zamanlı çalışanın işini kaybetmesi anlamına gelmektedir. $\mathrm{Bu}$ rakamlar, Arap Devletlerinde \%8,1-5 milyon, Avrupa'da \%7,8-12 milyon; Asya-Pasifik'te \%7,2-125 milyon tam zamanlı çalışanın işini kaybetmesi anlamına gelmektedir. Yine farklı gelir gruplarından özellikle de üst-orta gelirli ülkelerde \%7-100 milyon tam zamanlı işgücü kaybı beklentiler arasındadır. Bu krizden en fazla etkilenecek sektörlerin, konaklama, gıda, imalat, perakende ve hizmet sektörünün olması beklenmektedir (Acosta, 2020). Bu rakamlar, COVID-19 salgını sebebiyle yakın dönemde yaşanan en önemli ekonomik krizle karşı karşıya kalınabileceğini göstermektedir.

Salgın döneminde emtia fiyatlarında büyük oynaklıklar yaşanmış, küresel bazda maden ve dolar değerlerinde önemli artışlar gerçekleşmiştir. $\mathrm{Bu}$ durum tüm dünyayı etkilemekle birlikte özellikle gelişmekte olan ülkelerde daha yoğun hissedilecektir. COVID-19 sebebiyle küresel anlamda Ekonomik istikrarsızlık da bir ülkenin güvenliği açısından önemli bir faktör olarak değerlendirilebilecektir.

Eğitim, bireylerin kişisel gelişimi ve bireysel güvenlik ve güvenlik farkındalığı açısından önemli olduğu kadar devletler ve genel anlamda küresel güvenlik açısından da önemlidir. Sürdürülebilir bir küresel güvenlik algısı ancak devletler ve kurumları tarafından önceliklendirilmiş bir eğitim sistemi söz konusu olduğunda gerçekleştirilebilir. Eğitim yeterli ve etkin düzeyde sağlanabiliyorsa, yoksulluk, eşitsizlik, güvensizlik ve hastalıklarla mücadelede önemli ivme kat etmek mümkün olabilecektir (Nayef R F, 2020). Eğitimli bireyler, devletler ve uluslararası sistemin karşısındaki tehditlerin bilincindedir ve bunlara karşı alınabilecek önlemlere karşı duyarlıdır. 
COVID-19 salgını sebebiyle alınan tedbirler kapsamında pek çok ülkede eğitim kurumları salgın süresince kapanmış ve öğrenciler eğitim-öğretim açısından zorlu koşullara tabi olmuştur. $\mathrm{Bu}$ noktada eğitim sisteminin devamlılığı önemli bir sorundur.

Eğitim sisteminin sürdürülebilir hale getirilebilmesi için, salgın süresince uzaktan eğitim gibi alternatif yöntemlerin öğrencilere sağlanması, devletlerin güvenliği açısından önem arz etmektedir. Burada gerekli alt yapının ivedilikle kurulması, yeterli denetim mekanizmalarının oluşturulması, ihtiyaçların ivedilikle sağlanması gerekmektedir.

\section{Çevresel, Tarımsal ve Gıda Güvenliği Boyutlarıyla COVID-19}

Çevre, devletler ve küresel sistem için önde gelen güvenlik sorunlarından biridir. Yaşanabilir bir çevre, kaynakların temiz ve sürdürülebilir tutulması, kirliliğin önüne geçilmesi, bitki ve hayvan varlığı ile biyolojik çeşitliliğin korunması, devletler ve küresel sistem için temelde güvenlik algısını oluşturmaktadır.

COVID-19 salgını ile birlikte, çevresel sorunların da yaşanması söz konusudur. Genel eğilime bakıldığında, salgın sebebiyle dünya genelinde çevreye olan ilginin azalması söz konusudur. Kuşkusuz salgın, çevrenin kirletilmemesi, canlı varlığının korunması gibi hususları arka plana atmıştır. Fakat bu hususlara ilgisiz kalındığında yaşanabilecek sorunlar ortadadır.

Çevre konusunda diğer bir husus, çevresel bilincin artırılmasına yönelik dünya genelinde ortak çabaların artırılması gerekliliğidir. Salgının çevresel etkilerinin incelenmesine yönelik gerekli çabaların artırılması, çevresel krizlere uluslararası bir kriz yönetim mekanizması aracılığıyla müdahale, gelişmemiş ve gelişmekte olan ülkelerden ihtiyaç duyanlara yeterli desteğin verilmesi gibi hususlar, ulusal ve uluslararası güvenliğin sağlanması açısından çok önemlidir.

Salgın koşullarında dahi olsa, yerel yönetimlerden başlayarak ulusal ve uluslararası boyutta çevre koruma faaliyetlerinin gerçekleştirilmesi önemlidir. Çevre koruma açısından, ormanların muhafaza ve bakımı canlı varlıkların korunması, temizlik hizmetlerinin aksatılmadan yürütülmesi, tıbbi atıkların usulüne uygun depolama ve imhası gibi hususlarda motivasyonun yüksek tutulması gerekmektedir.

Tarım, toplumların beslenmesi açısından temel faaliyetlerden en önemlisidir. Tarım yapılabilir toprakların bulunması, yeterli ürün arzının sağlanması tarımsal toprakların korunması, çiftçiye yeterli eğitimin verilmesi, tohumun ve kullanılan ilaç-gübre gibi unsurların yeterli olması, sürdürülebilir bir tarım açısından büyük önem arz etmektedir

Tarım faaliyetleri, salgın döneminde de önemini artırmıştır. Toplumun genelinin evde olması, tarım ürünlerine yönelik ilgiyi de artırmıştır. Eskiden daha fazla ürün tüketimi söz konusu olacaktır.Buna göre, tarımsal faaliyetlerin devamının sağlanması, stokçuluğun ve fahiş fiyat artışlarının önüne geçilmesi büyük önem arz etmektedir.

$\mathrm{Bu}$ noktada, tarımsal ürünler açısından her dönemde hazırlık yapılması, tarım ürünleri açısından yaşanabilecek olumsuz durumlara karşı, belli miktarlarda devlet gözetiminde stok tutulması faydalı olacaktır.

Diğer bir husus gıda güvenliği hususundadır. Gıda güvenliği, insan ve hayvan gidalarının hijyeni ve sürdürülebilirliği ile ilgilidir. Gıda güvenliğinin sağlanması ile, bir taraftan ürünlerin tüketicilere, diğer bir taraftan da biyolojik, kimyasal ve fiziksel açıdan yaşanılan çevreye zarar vermesinin önlenmesi hedeflenmektedir (Tayar, 2010:4). Bu şekilde hem bireyler hem de çevre hastalıklar ve kirlilikten uzak tutulmuş olmaktadır. Bu durum, toplum sağlığı açısından çok önemlidir.

Gıda güvenliği konusu, COVID-19 salgını açısından da büyük önem arz etmektedir. Virüsün yayılma hızı ve bulaşıcılı̆̆ı dikkate alındığında, tüketicilerin korunması için özel önlemler alınması 
gerekmektedir. Ürünlerin üretilmesinden, paketlenmesine son tüketiciye ulaşan akadar bütün süreçlerde hijyen şartlarının sağlanması büyük önem arz etmektedir. Bu noktada uluslararası standartların uygulanması önemli fayda sağlayacaktır.

Bir diğer husus da gıda maddelerinin tedariği sorunudur. Salgının aylar içindeki seyri incelendiğinde, genel olarak dünya ülkelerinin önemli bir kısmında, güvenlik önlemleri gereği, kısitlı bir biçimde bireylerin dışarı çıktığı söylenilebilecektir. Bu durum, insanların ister istemez temel ihtiyaç maddelerine ulaşmakta sorun yaşamasına yol açmaktadır.

Temel gıda, içilebilir su ve ihtiyaç maddelerinde üretimin sürdürülmesi, lojistik ve depolama noktalarında sorun yaşanmaması için, salgın süresince önlem alınması gerekmektedir. Toplum içinde panik ve stoklamanın önüne geçebilmek için, bütün bu ürünlerin halka ulaştırılması, bu noktada gerekli denetim mekanizmalarının oluşturulması, gerekli durumlarda merkezi ve yerel yönetimlerin imkanlarının tedarik ve lojistik imkanlarının geliştirilmesi amacıyla kullanılması fayda sağlayacaktır.

Gıda maddelerinde arzın sürekli ve sürdürülebilir olması için tarımsal üretimin devam etmesi, taşımacılık sektöründe aksamaların önüne geçilmesi, yol ve ulaşım güvenliğinin sağlanması diğer önemli faktörlerdir.

\section{Silahlı Kuvvetler ve Asayiş Boyutlarıyla COVID-19}

Bütün dünyada etkili olan COVID-19 salgını ile mücadele eden önemli kuruluşlar arasında ülkelerin orduları gelmektedir. Ordular tarih boyunca geleneksel misyonları olan savaşa hazırlık ve savaş dışında, özellikle kriz anlarında ve doğal afetlerde aktif olarak görev almışlardır. Bu noktada güncel salgında da ülkelerin orduları önemli görevler icra etmektedir. Bu görevler arasında sağlık personeline yardımcı olunması, sahra hastaneleri kurulması, inşaatlar, ülkeler bünyesinde koruma görevleri gibi faaliyetler yer almaktadır.

Salgınlar ilgili olarak silahlı kuvvetler açısından diğer bir önemli husus, orduda görev yapan personelin salgından uzak tutulması gerekliliğidir. Ordular salgında aktif görev almakla beraber, aynı zamanda yapısı gereği salgından kolay etkilenebilecek kurumlar arasındadır. Çok sayıda personelin sürekli bir arada bulunduğu düşünüldüğünde, personelin salgından korunması için özel önlemler alınması gerekliliği ortadadır. Görevin özel durumu gereği, orduların personel sayısında azaltma güvenlik zafiyeti oluşturabileceğinden, ordu teyakkuz halinde olmalı ve alınabilecek en yoğun önlemlerle ordu personelinin salgından uzak tutulması sağlanmalıdır. Ordu personeline COVID-19 ile mücadele yöntemleri öğretilmeli, salgında sivil birimlerle işbirliği haline çalışabilmeleri için simulasyonlar hazırlanmalı ve bu şekilde salgınla mücadele edilmelidir.

Silahlı kuvvetlerle ilgili diğer bir husus da ülke güvenliğine ilişkin faaliyetlerin devam ettirilmesi zorunluluğudur. Ulusal güvenlik, hiçbir koşulda aksatılamayacak bir olgudur. Salgında yaşanabilecek risklere rağmen, maksimum tedbirlerin alınarak, kara, hava ve deniz sınır güvenliğinin sürekli sağlanması bir zorunluluktur. Bununla birlikte ülke içinde güvenliğin sağlanmasına yönelik gerekli önlemlerin de alınması gerekmektedir. Terör, kaçakçılık insan kaçakçılığı, uyuşturucu ticaretiyle mücadele gibi temel alanlarda da faaliyetlere ara vermeden devam edilmesi gerekmektedir.

Salgın sebebiyle ülkelerde özellikle büyük ve kalabalık şehirlerde nüfusun önemli bir kısmının evlerinde yaşaması söz konusudur. Bu durum, salgın sırasında asayiş sağlanmasında önceki dönemlere nazaran daha sakin bir dönem yaşanmasına neden olabilecektir.

Salgın sebebiyle çoğu ülkede şehirlerarası seyahat kısıtlanmış, bu nedenle de halk bir anlamda bulundukları bölgelerde sınırlı bir özgürlük çerçevesinde hareket etmektedir.

Amerika Birleşik Devletlerinde Chicago'daki suç istatistikleri değerlendirildiğinde, uyuşturucu kaçakçıllğ̆ ile ilişkili suçlarda geçen yıla göre, yüzde 42'lik bir düşüş söz konusudur. Kentteki genel suçlardaki düşüşün ise yüzde 10'un üzerinde olduğu ifade edilmektedir. Dünyada en 
çok suç oranlarının olduğu Latin Amerika ülkelerinde, özellikle cinayet oranlarında ciddi bir düşüş olduğu tespit edilmiştir. Aynı şekilde geçen sene El Salvador'da günde 600 kişi öldürülürken bu sayı bu sene bu sayı günde 2'ye kadar düşmüştür. Peru'da ise geçen seneye kıyasla, suç oranlarında yüzde 84'lük bir düşüş kaydedilmesi söz konusudur (Lederer, 2020). Bu durum salgının suç oranlarında önemli bir düşüş getirdiğini göstermektedir. Aynı durumu klasik olarak ifade edilebilen özgürlük güvenlik ikilemi ile de açıklamak mümkündür.

Özgürlük ve güvenlik arasında bir ikilem bulunduğuna ilişkin teoriye göre, özgürlükler arttıkça, güvenlik sorunları çoğalmakta, ters mantıkla düşünüldüğünde de güvenli olmak özgürlüğü bırakmak anlamına gelmektedir. Bu ikilem özellikle insan hakları savunucuları tarafından sıklıkla gündeme taşınmaktadır.

Farklı bir görüşe göre de özgürlük ve güvenlik pek çok durumda birbirinin "mütemmim cüz”ü durumdadır. Özgürlügün olmadığı yerde güvenliğin de bulunmaması söz konusudur. Bu anlamda, güvenliğin bazı koşulları bulunmadı̆̆ 1 durumlarda, birey özgürlüğünden de bahsedilemeyecektir. Aynı görüsse göre, bir bireyin özgürlük ve güvenlik çıkarları, çoğunlukla birliktedir. Bir bireyin güvenliğini artıran pek çok önlem aynı zamanda onu daha fazla özgürleştirecektir (Erdoğan, 2013:23). Bu görüş, özgürlük ve güvenlik olgusu arasında bir ayrım yapılamayacağını, farklı bir ifadeyele birlikte değerlendirilmesi gerektiğini ifade etmektedir. Bununla birlikte bu görüş, iki kavramın nadiren de olsa birbirleriyle çelişebileceğini, farklı çıkarların olduğu durumlarda birbirlerine rakip olabileceklerini de kabul etmektedir.

Özgürlük ve güvenlik konusunda üçüncü bir bakış açısı da iki kavramın arasında bir denge olması gerektiği, özgürlük ve güvenlik konusunda bir uyum yakalanabilmesi için gerek özgürlük gerekse güvenlik konusunda karşılıklı ödünler verilmesi söz konusu olduğu durumlarda; bir dengeden de söz edilebileceğini ifade etmektedir. Bununla birlikte bu görüş özellikle 11 Eylül saldırıları sonrasında önemli ölçüde eleştirilmiştir. Eleştiriler özgürlük ve güvenlik arasında bir dengenin olmasının mümkün olmadığı, iki kavram arasında da bir gerilim bulunmasının en muhtemel bakış açısı olduğu ve birini geliştirmek söz konusu olduğunda, diğerinden ödün vermek gerektiğini ifade etmektedir (Wittes, 2011:6).

Son noktada özellikle insanların özgürlüklerinin önemli ölçüde kısıtlandığı COVID-19 salgını ile birlikte, suç işleme imkanlarının da kısıtlanması, suç unsurlarının ve örgütlerin de salgından etkilenmesi, toplumların genelinin evde kalması sebebiyle, suç unsurlarının açık hedef haline gelmesi, güvenlik güçlerinin daha rahat hareket etmesi gibi gerekçelerle, dünya genelinde suç oranlarında önemli azalmalar meydana gelmesi muhtemeldir.

Salgında iç güvenlik birimlerine ilişkin, sürekli görev yapılmasına imkan tanıyacak koruyucu ekipman sağlanması ve gerekli eğitimlerin verilmesi büyük önem arz etmektedir. İç güvenlik noktasında yaşanabilecek aksamalar, büyük bedeller ödenmesine neden olabilecektir.

İç güvenlik birimlerinin salgındaki önemli bir misyonu, salgının önlenmesine ilişkin alınabilecek tedbirlerin uygulanmasının sağlanmasıdır. Aynı şekilde, asayişin sürdürülmesi, görevli personellerin korunması, kilit kurumların ve sektörlerin tehlikelere karşı korunması ve düzenin tekrar sağlanabilmesi için çalışmalar gerçekleştirmek iç güvenlik birimlerin sorumluluğundadır.

\section{Terörizm Boyutuyla COVID-19}

Terör örgütleri siyasal amaçları doğrultusunda eylemler gerçekleştirmektedir. Örgütler, tıpkı bir virüsün insan vücuduna yerleşip uykuya geçerek bağışıklık zayıfladığında, vücudu etkisi altına alması gibi, ülkelerin zor durumlarından mümkün olduğunca faydalanmaktadır.Bu bakış açısı, belirli bir ülkedeki durumla ilgilidir. Ancak küresel bir salgın söz konusu olduğu için bütün dünyanın terör tehdidine açı olması söz konusudur. 
Dünya genelinde 2020'nin başından itibaren gerçekleşen terör eylemleri incelendiğinde, toplam 26 eylem gerçekleştiği ve 446 kişinin öldügüü görülmektedir. Aynı dönem için, 2019 rakamları incelendiğinde ise, 28 saldırıda 594 kişinin öldürüldüğü görülmektedir. Terör eylemlerinin daha yoğun gerçekleştiği 2018'in aynı döneminde ise, 574 saldırıda 2279 kişinin öldüğü görülmektedir. 2017 rakamlarına bakıldığında, 54 saldırıda, 1.064 kişinin öldüğü görülmektedir (ESRI, 2020). Bu rakamlardan yola çıkarak şu aşamada küresel açıdan COVID-19 salgınının terör eylemlerine yönelik önemli bir etkisinin bulunmadığ ifade edilebilecektir.

Bununla birlikte bölgesel eylemler değerlendirildiğinde, COVID-19 salgını döneminde özellikle Afrika'daki terör eylemlerinde önemli artış gerçekleştiği ifade edilebilecektir. Batı Afrika'da Boko Haram Terör örgütünün eylemlerinde önemli oranda artış gerçekleşmiş, yine DAEŞ bağlantılı teröristler Mozambik'te bir bölgeyi kontrolü altına almıştır (DW, 2020). Buna göre, özellikle güvenlik açısından yeterli altyapıya sahip olmayan devletlerde terörizmin salgının yarattı̆ğ ortamdan faydalanarak artış gösterdiği ifade edilebilecektir. Bu durumda, bölgedeki uluslararası destek mekanizmalarının salgın döneminde yetersiz kalması, yine güvenlik güçlerinin salgından etkilenmesi gibi faktörler etkili olmaktadır.

COVID-19 ve terörizm ilişkisi noktasında önemli olan hususlardan bir tanesi, salgının yarattığı küresel ilgi kayması sebebiyle, terör örgütlerinin özellikle zayıf devletler nezdinde kendilerine daha rahat "safe-haven" imkanı bulabilmesidir. Örgütler, ülkelerin, küresel örgütlerin ve doğal olarak yerel halkların ilgisinin salgına kayması sebebiyle ortaya çıkabilecek firsatları değerlendirilebilecektir.

COVID-19'un yayılma hızı, dünya çapında yarattığı devasa etki, terör örgütlerinin sansasyonel eylem gerçekleştirme ihtiraslarını da kamçılayabilecektir. COVID-19'un bütün dünyaya yayılması, öldürme oranlarının yüksekliği, gelecekte terör örgütlerinin eylem tarzlarında da önemli farklılıklar yaratabilecektir. Eylemlerde, bulaşıcılığg yüksek virüs, bakteri gibi biyolojik silahların kullanılabilecek olması, terörle mücadele stratejilerinde de önemli bir revizyon gerekebileceğini göstermektedir. Buna göre gelecekteki biyolojik terörizm hareketlerine karş1, dünya genelinde terörle mücadele stratejileri içerisinde, virolojistler, bakteriyologlar, biyologlar, laborantların istihdam edilmesi gerekecektir. Yine güvenlik ve sağlık kuruluşlarınca, biyolojik terörle mücadeleye özel önem verilmesi ve, biyolojik teröre özel birimler oluşturulması, var olan birimlerinde de güçlendirilmesi gerekecektir.

\section{İstihbarat Boyutuyla COVID-19}

En basit tanımıyla "haber alma" anlamında kullanılan istihbarat, kuşkusuz devletlerin önemli güvenlik mekanizmalarından birisidir. COVID-19'un güvenliğin pek çok alanını etkilediği gibi, istihbarat alanında da önemli etkiler doğurması söz konusudur. Geleneksel olarak istihbarat teşkilatları, faaliyetlerini HUMINT olarak da ifade edilen insan istihbaratı faaliyetleriyle toplarlar. İnsan istihbaratı insanlar arasında bulunan istihbaratçılar aracılığıyla toplanmaktadır. Bununla birlikte, COVID-19 salgını ile birlikte, insanların bir arada bulunması sınırlandığından, istihbarat toplama faaliyetleri elektronik istihbarat, sinyal istihbarat, internet ve sosyal medya üzerinden gerçekleştirilen istihbarat faaliyetleriyle gerçekleşecektir.

Günümüzde dünyanın internet ve cep telefonu kullanım istatistikleri değerlendirildiğinde, 7,75 milyara ulaşan toplam insan nüfusu içinde yaklaşık 5,19 milyar insanın cep telefonu kullanıcısı olduğu, yine 4,54 milyar insanın internet kullandığ 1 , 3,8 milyar insanın da aktif sosyal medya kullanıcısı olduğu görülmektedir (we are social, 2020). Bu rakamlardan yola çıkarak, dünya nüfusunun yaklaşık yüzde 70'inin cep telefonu, yaklaşık yüzde 60'ının internet ve yaklaşık yüzde 50 'sinin aktif internet kullanıcısı oldukları ortaya çıkmıştır. Bu veriler, özellikle sosyal medya kullanan bireylerin bütün bilgilerinin, sosyal medya şirketlerinin elinde olması, aynı zamanda da istihbarat örgütlerinin iştahını kabartmaktadır. Günümüzde insan nüfusunun yüzde 50'sinin sosyal 
medya kullanıcısı olduğu değerlendirildiğinde, 3,8 milyar insanın kişisel bilgileri, fotoğraf ve belgeleri, sosyal medyadadır. Bu aynı zamanda istihbarat elde etmek için internette yapılabilecek basit aramalarla, ulaşılmak istenen bütün bilgilere ulaşmayı sağlamaktadır. Bu anlamda COVID-19 salgını, istihbarat toplama yöntemlerindeki değişimi hızlandırmıştır.

COVID-19 ile birlikte önemi artan istihbarat faaliyetlerinden birisi de "Sağlık İstihbaratı" kavramıdır (Şen, 2020). Sağlık istihbaratı medikal istihbarat (Medical Intelligence-MEDINT) olarak da adlandırılmaktadır. "Dost güçlerin savaş gücünün korunması ile yabancı sivil ve askeri sektörlerde sağlık imkanlarının değerlendirilmesi amacıyla gerçekleştirilen operasyonlar, stratejik planlama ve askeri sağlık planlamalarıyla ilgili olarak, yabancı tıbbi, bio-bilimsel ve çevresel bilgilerin toplanması, değerlendirilmesi, analizi ve yorumlanmasından kaynaklanan istihbarat türüdür" (U.S. Department of Defense, 2010:183). Buna göre, sağlık istihbaratının öneminin artmasıyla birlikte, ülkeler arasında yeni bir mücadele alanı daha ortaya çıkacaktır. Ülkeler açısından ilaç üretimi, aşı geliştirme çalışmaları, sağlı yatırımları ve harcamaları güvenlik algısını değiştirecek, ülke istihbarat teşkilatlarının yeni görev alanlarından biri, sağlık alanında başka ülkelerdeki gelişmelerin takibi aynı zamanda da sağlık istihbaratına karşı koyma olacaktır. Bu noktada ülkelerin güvenlik ve istihbarat teşkilatlarında sağlı istihbaratı ile ilgili birimler kurulması, bu alanda personel yetiştirilmesi ve istihdamı önem kazanacak, ülkelerin güvenlik ve beka algısını değiştirecektir.

\section{Uluslararası Güvenlik Kuruluşları Boyutuyla COVID-19}

COVID-19'un hızlı bir biçimde yayılması ve bütün dünyada etkisini göstermesiyle, uluslararası örgütlerin ülkelere verdikleri destekler önem kazanmıştır. Bu noktada özellikle Birleşmiş Milletler, NATO, Avrupa Birliği gibi kuruluşların COVID-19 ile mücadeledeki performansları incelenmiştir.

Birleşmiş Milletler COVID-19 salgınının başlangıcından itibaren COVID-19 ile ilintili farklı alanlarda pek çok faaliyet gerçekleştirmektedir. Buna göre, Birleşmiş Milletler'in temel misyonu doğrultusunda, COVID-19 salgını ile mücadelede ülkelere ve bölgelere yönelik destek sağlamaktadır. $\mathrm{Bu}$ doğrultuda, Barış Koruma faaliyetleri kapsamında yürütülen operasyon ve denetlemelerin devamlılığ sağlanmakta, bağlı kuruluş olan Uluslararası Göç Örgütü’nün faaliyetleri kapsamında, sınır ötesi koordinasyon, nüfus hareketliliği, haritalama egzersizleri, risk iletişimi ve toplum katılım faaliyetleri ve hükümet çalışanları için eğitim ve simülasyonlar gerçekleştirilmesi, terörizm ve uyuşturucuyla mücadele konusunda, Birleşmiş Milletler Uyuşturucu ve Suç Ofisi'nin (UNODC), yürüttüğü çalışmalar kapsamında uyuşturucu kullanımının önlenmesi, uyuşturucu kullananlar ve HIV virüsü hastalarının mevcut salgından etkilenmesinin önlenmesi, siber suçlar dahil salgından faydalanarak işlenmek istenen suçların önlenmesi, mültecilerin sağlık koşullarının iyileştirilmesi gibi pek çok alanda önlemler almaktadır(Birleşmiş Milletler, 2020).

Birleşmiş Milletler Güvenlik Konseyi, yaşanılan dönemdeki gibi küresel boyuttaki salgınları uluslararası barış ve güvenliğe karşı bir tehdit unsuru olarak görebilmektedir. 2014'te 2177 Sayılı Karar ile Ebola Salgınında Birleşmiş Milletler Antlaşmasının 39. Maddesi uyarınca, bir sağlık sorunu, uluslararası barış ve güvenliğe karşı bir tehdit unsuru olarak görülmüştür(Svicevic, 2020). Benzeri bir kararın COVID-19 için de alınması salgınla mücadele açısından ivme kazandıracaktır.

NATO özellikle birimlerinin bulunduğu ülke ve bölgelerde personelin COVID-19'dan korunmasına ilişkin tedbirler almış, bilgilendirici ve önleyici faaliyetler gerçekleştirmektedir. $\mathrm{Bu}$ amaçla Birleşmiş Milletler ve Dünya Sağlık Örgütü öncülüğünde uluslararası örgütlerle işbirliğgi gerçekleştirmektedir (NATO, 2020).

COVID-19 süresince Avrupa Birliği, üye ülkelere destek sağlamakta, özellikle koruyucu ekipman ve bilgilendirici faaliyetlerde öncülük etmektedir. Üye ülkelere maddi destek, sağlık personeli ve tıbbi destek sağlama noktasında faaliyetlerini sürdürmektedir. Avrupa Birliğinin ayrıca 
çevre ülkeler ve COVID-19'dan daha fazla etkilenen Avrupa Birliği'ne komşu ülkelere de destek sağlaması söz konusudur (Avrupa Birliği, 2020).

Bütün bu uluslararası çabalar, olumlu olsa da dünya çapında gerçekleşen bu salgında uluslararası örgütlerin çalışmalarının yeterli olduğu söylenemeyecektir. Uluslararası örgütler, yaşanan büyük krizde verdikleri sınavda büyük ölçüde başarısız olmuştur. Başlangıçta salgına karşı yeterli ilgi gösterilmemiş, salgın ciddiye alınmamış gerek kuruluşların üyeleri gerekse dünyanın tümünde COVID-19 salgınına ilişkin yeterli bilgi ulaştırılamamıştır.

Gelecekte de benzer sorunların meydana gelmesi olasılı̆g 1 dikkate alınarak, gerek ülkeler gerekse farklı uluslararası örgütler arasında işbirliği imkanlarının araştırılması, söz konusu kuruluşlarda salgınlarda liderlik edecek birimler oluşturulması, yine ülkeler nezdinde salgın ülke ve bölge koordinasyon birim ya da personelleri belirlenerek, periyodik olarak eğitimler verilmesi, salgın simülasyon ve tatbikatları gerçekleştirilmesi yerinde olacaktır.

\section{Sonuc}

Çin'de ortaya çıkarak bütün Dünya'ya yayılan ve son dönemin en büyük felaketlerinden biri olarak tarihe geçecek COVID-19 salgını, dünyada pek çok alanda etki yaratmaktadır. Sağlık, tarım, çevre, eğitim ve ekonomik olarak pek çok sorunla başbaşa kalan dünyada en önemli sorunlardan birisinin de güvenlik olması beklenmektedir.

Diğer alanlardan olduğu gibi güvenlik alanında da, COVID-19 sonrasında pek çok şey eskisi gibi olmayacaktır. Diğer alanlarda yaşanan sorunlar da aslında bir güvenlik ve beka sorunu ortaya çıkarmaktadır. En gelişmiş ülkeler dahi, hayati sektörlerde yaşanan krizleri aşmakta zorlanmakta, bu da devletlerin bekası ve bireylerin güvenliğini tehlikeye atmaktadır.

Artık ülkelerin kriz anlarında yaşayabilecekleri sorunlar acı tecrübelerle ortaya çıkmış, yaşanabileceklere ilişkin eylem planlarının bulunması zorunluluğu görülmüştür. Dünya en kötü senaryolara karşı simulasyonlar geliştirmeli, risk gerçekleştiğinde alınabilecek önlemlere ilişkin önceden çalışmalar yapılmalıdır.

Gelecekte de benzer sorunlarla karşılaşılabileceğinden hareketle, ülkeler güvenlik alanında yaşanan tecrübeleri de dikkate alarak, ordular, iç güvenlik birimleri, istihbarat teşkilatları gibi güvenlik kurumlarında gerekli değişim ve dönüşümleri gerçekleştirmelidir. Güvenlik kuruluşları her koşulda çalışabilme esasına göre yapılandırıldığından, salgın gibi bir durumla karşılaşıldığında alınabilecek önlemlere ilişkin eğitim, personel istihdamı gibi hususlarda gerekli yatırımları gerçekleştirmelidir.

Ülkelerin güvenliğini sağlama noktasında gerek ülke dışında gerekse ülke içinde önlemler alınarak, personelin salgından etkilenmeden görev yapabilmesi için gerekli koşullar sağlanmalıdır.

Kolluk güçleri ve iç güvenlik mekanizmaları, alınabilecek önlemlerin uygulanmasını etkili biçimde takip etmeli, toplumun genelinin sağlığının korunması için gerekli alt yapıyı sağlamalıdır.

Bakteri-virüs gibi biyolojik araçların yıkıcı etkisi tüm dünya tarafından görüldüğünden, bu unsurların silah amaçlı kullanımına karşı, gerekli savunma mekanizmaları oluşturulmalıdır. Biyolojik savaş potansiyelinin artması sebebiyle, ülkelerde biyolojik silahlara ilişkin yeterli personel istihdam edilmeli, sürekli eğitimler verilerek bu personelin etkinliği artırılmalıdır.

Güvenlik teşkilatlarında salgınlar ve biyolojik silahlara ilişkin sorumlu birimler oluşturulmalı, bu birimlerin verimliliği ve etkililiği sürekli olarak denetlenmelidir.

Terör örgütlerinin biyolojik terör eylemlerinin önüne geçebilmek için gerekli hazırlıklar yapılmalı, riskler değerlendirilerek önlem mekanizmaları geliştirilmelidir. Terör örgütlerinin yapılanmalarında, bu alanlarda eğitim görmüş kişilerin yer almasının önüne geçebilmek için stratejiler geliştirilmelidir. İstihbarat elde edilmesi amaciyla, çok faktörlü bir tarama 
gerçekleştirilmeli, yeni nesil terör örgütlerinin özellikle siber alanda örgütlenerek, faaliyetlerini sürdürdükleri dikkat alınarak, bu örgütlerle mücadelede gerekli mekanizmalar oluşturulmalıdır.

Yeni bir istihbarat alanı olarak kabul edilebilecek, sağlık istihbaratı alanında yeterli personel istihdamı sağlanmalı gerek istihbarat toplamada gerekse istihbarata karşı koyma amaçlı gerekli çalışmalar gerçekleştirilmelidir.

Salgınlarda ulusal mücadele ile birlikte, uluslararası kuruluşlarla maksimum koordinasyon sağlanmalı, Birleşmiş Milletler, NATO, Avrupa Birliği gibi kuruluşlarda salgınların önlenmesine ilişskin politikalar geliştirilmeli ve bunların denetimi sağlanmalıdır.

Salgın Birleşmiş Milletler Güvenlik konseyinde ele alınmalı ve uluslararası güvenliğe yönelik bir tehdit olarak değerlendirilmelidir. Bu yönde alınacak kararlar, ülkeler üzerinde, önemli etki yaratarak, salgınla mücadelede ivme kazandıracaktır.

\section{Kaynakça}

Acosta, L. (2020). ILO. https://www.ilo.org/global/about-theilo/newsroom/news/WCMS_740893/lang--en/index.htm (12.04.2020).

Asya Kalkınma Bankası. (2020). Asya Kalkınma Bankası.

https://www.adb.org/news/developing-asia-growth-fall-2020-covid-19-impact (12.04.2020).

Avrupa Birliği. (2020). Crisis Management and Solidarity. https://ec.europa.eu/info/live-worktravel-eu/health/coronavirus-response/crisis-management-and-solidarity_en (19.04.2020).

Birdişli, F. (2014). "Eleştirel Güvenlik Çalışmaları Kapsamında Frankfurt Okulu ve Soğuk Savaş Sonrası Güvenlik Sorunlarına Eleştirel Bir Yaklaşım: Galler Ekolü”. Güvenlik Stratejileri Dergisi. 10 (20), 229-256.

Birleşmiş Milletler. (2020). Coronavirus. https://www.un.org/en/coronavirus (19.04.2020).

Defense, U.S. Department of. (2010). Dictionary of Military and Associated Terms. https://usacac.army.mil/sites/default/files/misc/doctrine/CDG/cdg_resources/manuals/jps/jp 1_02.pdf (18.04.2020).

DW. (2020). Increased Terror Attacks in Africa Amid Coronavirus Pandemis https://www.dw.com/en/increased-terror-attacks-in-africa-amid-coronavirus-pandemic/a53066398 (18.04.2020).

Erdoğan, M. (2013). “Anayasal-Demokratik Bir Rejimde Özgürlük ve Güvenlik”.Istanbul Ticaret Üniversitesi Sosyal Bilimler Dergisi.12 (24), 21-29.

ESRI. (2020). Terorist Attacks. https://storymaps.esri.com/stories/terrorist-attacks/ (16.04.2020).

Kolasi, K. (2014). Eleştirel Teori ve Güvenlik:Kimin İçin Güvenlik? https://www.researchgate.net/publication/321062246_elestırel_teor1_ve_guvenl1k_k1min_1c 1n_guvenlik (19.04.2020).

BBC İnternet Sitesi. Koronavirüs nedir: COVID-19'a Karşı Hangi Önlemler Alınmalı, Virüsün Özellikleri Neler? https://www.bbc.com/turkce/haberler-dunya-51177538 (12.04.2020).

Lederer, E. M. (2020). Crime Drop Coronavirus. Time:https://time.com/5819507/crime-dropcoronavirus/ (16.04.2020).

Mph Online. (2020). Worst Pandemics in History. https://www.mphonline.org/worst-pandemics-inhistory/ (12.04.2020). 
NATO. (2020). https://www.nato.int/cps/en/natohq/news_174271.htm (19.04.2020).

Nayef R F, A.-R. (2020). Honore Champion: https://www.honorechampion.com/gb/diffusions/9634book-05102036-9782051020367.html (16.04.2020).

Ovalı, A. Ş. (2006). "Ütopya İle Pratik Arasında: Uluslararası İlişkilerde İnsan Güvenliği Kavramsallaştırması”. Uluslararası İlişkiler Dergisi, 3 (10), 3-52.

Svicevic, M. (2020). COVID-19 as a Threat to International Peace and Security: What place for the UN Security Council? https://www.ejiltalk.org/covid-19-as-a-threat-to-international-peaceand-security-what-place-for-the-un-security-council/ (19.04.2020).

Şen, U. B. (2020). COVID-19 Gölgesinde İstihbarat Savaşlarl. Star Gazetesi https://www.star.com.tr/acik-gorus/covid-19-golgesinde-istihbarat-savaslari-haber1529838/ (18.04.2020).

Tayar, M. (2010). Gıda Güvenliği. İstanbul: Marmara Belediyeler Birliği .

TUIC Akademi. (2016). İnsan Güvenliği Çevre Gida Saglik Birey. http://www.tuicakademi.org/insan-guvenligi-cevre-gida-saglik-birey/ (18.04.2020).

Virus Ncov. (2020). https://virusncov.com/ (23.06.2020).

Walt, S. (2017). Realism and Security. Oxfordre: https://oxfordre.com/internationalstudies/view/10.1093/acrefore/9780190846626.001.0001/ acrefore-9780190846626-e-286?print=pdf (19.04.2020).

We Are Social. (2020). 3,8 Billion People Use Social Media. https://wearesocial.com/blog/2020/01/digital-2020-3-8-billion-people-use-social-media (18.04.2020).

Wittes, B. (2011). Against a Crude Balance: Platform Security and the Hostile Symbiosis Between Liberty and Security. Brookings: https://www.brookings.edu/wpcontent/uploads/2016/06/0921_platform_security_wittes.pdf (16.04.2020).

Wolfers, A. (1952). "National Security" as an Ambiguous Symbol". Political Science Quarterly, 67 (4), 481-502. 